\title{
Society and Range Management: A Commentary
}

\author{
JOHN E. MITCHELL AND MARK W. BRUNSON
}

\begin{abstract}
Authors are range scientist, Rocky Mountain Forest and Range Experiment Station. Fort Collins, Colo. 80524; and assistant professor, Dept. of Forest Resources, Utah State Univ., Logan 84322, respectively.
\end{abstract}

The 3 papers which follow this prologue were originally presented at the Fifth International Symposium on Society and Resource Management, held 7-10 June 1994 at Colorado State University, Fort Collins. The symposium focused on creating partnerships among natural resource professionals in research, education, and management. Nearly 500 papers were presented by attendees representing a dozen countries. Most of them were social scientists and economists; relatively few range scientists or range managers were present.

It is somewhat paradoxical that an international conference dealing with human dimensions issues of natural resource management should attract so little attention from those of us who have specialized in the stewardship of rangelands. While we all acknowledge the importance of how social issues are impacting rangeland management-particularly those on federal and state lands in the United States-many of us, like other natural resource professionals, tend to feel uncomfortable addressing societal concerns. Our lack of training in social sciences certainly inhibits us. Also, social problems are often perceived as being insolvable because of non-compromising interest groups. Whatever the reasons, we lag far behind several other natural resource professions in exploring interrelationships between the human and bio-physical dimensions of our discipline.

The dilemma at the Fifth International Symposium was not one of a dearth of appropriate subjects being covered. Although the word "rangelands" did not appear in many papers, topics germane to rangelands were presented; e.g., papers on risk assessment, ecosystem management, and the changing resource management work force. Regardless, the human dimensions of rangelands will remain relatively unexplored without personal interactions between the kinds of people who tend to belong to the Society for Range Management, and the kinds of people-social scientists and economists-who attended the Fifth International Symposium. Partnerships cannot form without a mechanism for interaction.

If the emerging concept of ecosystem management is to succeed as a national policy, opportunities for synthesizing the crucial components of social values and ecosystem health, as they relate to long-term sustainability and other ingrained goals, must be increased. The utilitarian conservation movement of the early 1900's, based soley on rigorous science and professionalism, has been modified by the environmental movement. The latter concerns itself with raising questions (and asking for answers) about the intrinsic value of nature, impacts of management on human lifestyles, and other complex matters. The science behind the environmental movement draws upon broadly divergent elements: economics, conservation biology, and sociology, to name 3 .

The Society for Range Management is well-suited to have a significant influence on strategic approaches for integrating societal values into natural resource management. We are a widespread and diverse community, particulary within the United States. Just as importantly, the Society frequently solicits viewpoints from other organizations at its meetings and symposia. To achieve a closer association between socioeconomic and bio-physical disciplines, however, those of us with training and experience in range management or science need to proactively look for ways to interact on their own turf with people whose principal interests are in applying social science to managing grazing lands. When feasible, we also need to read and publish in journals that reach this wider readership, e.g., Society and Natural Resources, and Land Economics, just as more work pertaining to human dimensions applications needs to be reported in the Journal of Range Management.

Range management has only recently become prevalent as a social issue on a national scale. Thus, we have a chance to learn from past mistakes and avoid some of the pitfalls that have befallen other resource management professions. When the Sixth International Symposium on Society and Natural Resources is held in May 1996 at Penn State University, we hope that more SRM members are able to attend, participate, and interact-essentially to infiltrate with a goal of revealing the national and global importance of rangeland management as a social issue. People with technical skills in ecology, animal science, soils, etc. will be just as essential at their symposium as are social scientists and their colleagues at SRM meetings. 